\title{
Promotion of Fintech Application for the Modernization of Banking-Finance System in Vietnam
}

\author{
Dat Dinh NGUYEN ${ }^{1}$, Hoang Cong DINH², Duy Van NGUYEN³
}

Received: March 18, 2020 Revised: March 28, 2020 Accepted: May 07, 2020

\begin{abstract}
In today's financial industry, Fintech (financial technology) has showed its role of an innovation-driving area, which can bring outstanding changes to the traditional financial market. This article will briefly introduce Fintech as well as its development in Vietnam. Besides, the research also provided a survey on experts' opinions on the challenges to the promotion of Fintech application for the modernization of the banking-finance system in Vietnam. The survey results of 40 experts in banking with knowledge of Fintech identify five challenges faced by Fintech companies in Vietnam: (1) legal corridor; (2) infrastructure; (3) Fintech companies; (4) customers; and (5) human resources. From these five challenges/barriers, there are 14 detailed aspects. The results of the expert survey using descriptive statistics show that all five factors are assessed to be low and need to be better addressed in the future. The authors suggest several solutions for further development of Fintech to support the modernization of the banking-finance system in Vietnam: (1) quickly complete the regulatory framework; (2) introduce policies on tax exemption; (3) promote research and application of the benefits of block-chain technology; (4) utilize the abilities of the human resources; and (5) actively promote and popularize knowledge about Fintech.
\end{abstract}

Keywords : Banking-Finance System, Fintech Application, Fintech, Vietnam.

JEL Classification Code: B26, C33, G40.

\section{Introduction}

Fintech (or financial technology) is evaluated as an important innovation in the financial industry and is showing fast development thanks to the growth of information technology, the sharing economy and favorable regulations (Lee et al., 2018; Nguyen, 2020). According to the Economist (2015a), Fintech is expected to trigger reforms in the financial industry since it can improve the quality of financial services, reduce costs, provide a more diversified financial landscape,

${ }^{1}$ First Author. Faculty of Banking and Finance, Foreign Trade University, Vietnam. Email: datnd@ftu.edu.vn

${ }^{2}$ Institute for Africa and Middle East Studies (IAMES), Vietnam Academy of Social Sciences (VASS), Vietnam.

Email: hoang0108@gmail.com

${ }^{3}$ Corresponding Author. QAGlobal, Hanoi, Vietnam [Postal Address: 9/82 Chua Lang Street, Dong Da District, Hanoi, 100000, Vietnam] Email: duynguyen.qa@gmail.com

(c) Copyright: The Author(s)

This is an Open Access article distributed under the terms of the Creative Commons Attribution Non-Commercial License (http://Creativecommons.org/licenses/by-nc/4.0/) which permits unrestricted noncommercial use, distribution, and reproduction in any medium, provided the original work is properly cited. and increase the sustainability. Technology innovations in terms of data analytics, infrastructure, big data, and mobile devices facilitate Fintech start-ups to disintermediate conventional financial companies through their unique and customized products and services. PwC (2016) stated that over $80 \%$ of financial institutions believe that Fintech start-ups can bring many risks to their business. Since Fintech companies are becoming increasingly important in the financial industry, financial companies now focus on how to build capabilities and invest in Fintech to ensure competitiveness in the market.

Accenture (2016) reported that the amount of investment in Fintech companies has been impressive, with USD5.3 billion in the first quarter of 2016, which is $67 \%$ higher than the investment amount at the same period in 2015. Moreover, the investment amount for Fintech firms in Asia-Pacific and Europe doubled to $62 \%$. Most of the investment in Fintech companies is from conventional financial institutions. These financial institutions invest in Fintech companies in the form of collaborative ventures; and invest in developing their own Fintech projects with the hope to achieve Fintech innovation and competitive advantages. 
In 2015, KPMG produced an annual report on Fintech companies. The US and China were evaluated as the two nations with the highest level of development of Fintech companies and start-ups. Holland Fintech (2015) predicted that a total of USD660 billion could be transferred from conventional financial services to Fintech ones in lending, payment, wealth management and crowd-funding. From the above, it can be seen that Fintech now plays an important role in the financial market.

\section{Fintech Business Models}

Accenture (2016) reported that USD50 billion was the investment amount for 2,500 Fintech companies in 2010. These companies have changed the method of saving, storing, investing, borrowing, spending, moving and protecting people's money. Six business models of Fintech companies have been identified, namely, wealth management, payment, lending, crowd-funding, insurance services, and capital market. In the next part, the operation, value propositions and main Fintech companies will be explored.

\subsection{Payment Business Model}

Compared to other services in the financial industry, payments are simpler. Thus, Fintech companies, which follow a payment business model can quickly gain customers and incur fewer costs. In addition, these companies can adopt innovations and new payment capabilities at a very fast speed. There are two markets for payment Fintechs, namely, the wholesale and corporate payment; and the consumer and retail payment. Payment for retailed financial services is performed on a daily basis and is the financial services with the least regulated feature. BNY Mellon (2015) summarized that consumer and retail payment Fintechs provide P2P mobile payments, real-time payments, mobile wallets, foreign exchange and remittances, and digital currency solutions. By using these services, customers can enjoy a quick, convenient payment experience whose accessibility can be secured through many channels.

Mobile payment services are becoming increasingly popular thanks to their convenience and security. Mobile payment services that can be conveniently and securely used on mobile devices are a popular business model. According to Li (2016), mobile payment can be conducted through nearfield communication (NFC), QR code or bar code, phone bills, use of credit cards on mobile websites, direct mobile payment or use of a mobile phone card reader. Typical examples of NFC applications are Samsung Pay, Google Wallet and Apple Pay. In addition, P2P payment services are also known as a popular payment business model since they allow users to transfer money to each other using Venmo or Paypal without additional charges.

\subsection{Wealth Management Business Model}

Robo-advisors are well-known examples of wealth management Fintech business models. These automated advisors can give users financial advice at a much lower cost than a real advisor by using algorithms to find potential assets for investment by users based on their characteristics and preferences in investment (The Economist, 2015b). According to Holland Fintech (2015), the development of this business model is based on the fact that nowadays, people prefer to receive automated and passive investment strategies, pay transparent costs, and invest in unit economics with small amounts of funding. A CFA survey conducted in 2016 revealed that respondents care most about how Fintech companies in the wealth management sector show their disruptive characters (Sanicola, 2016).

\subsection{Crowd-funding Business Model}

According to International Trade Administration (International Trade Administration, n.d.), crowd-funding Fintechs support networking to create new media, ideas and projects, and mobilize funding for venture capital or charity. There are three parties participating in crowdfunding: the entrepreneur/initiators that need to mobilize funds, the funders who are interested, and the moderating organizations that help match the initiators and the funders by sharing information on the initiators' projects with the funders to help them come up with suitable solutions and funding options.

The most well-known crowd-funding business models include donation-based crowd-funding, reward-based crowd-funding, and equity-based crowd-funding. Mollick (2014) stated that in reward-based crowd-funding, the borrower is able to set the interest rate it can afford and the repayment duration, and then offers rewards to its project supporters. Thus, small businesses and creative projects can use this option for mobilization of funds. In donationbased crowd-funding, money is requested from donators for charity projects; and the donators will receive no monetary benefits except recognition. Equity-based crowd-funding is more suitable for SMEs since the requirements of traditional banks on capital ratio are difficult for SMEs to meet. By applying equity-based crowd-funding, entrepreneurs can meet investors who want to acquire equity in their new businesses.

The element, which differentiates equity-based crowdfunding from other types of crowd-funding, is that equity-based crowd-funding requires entrepreneurs to offer partial ownership of their business to exchange for funds. Indie-gogo, Kickstarter, RocketHub and CrowdFunder are examples of reward-based crowd-funding companies; GiveForward, FirstGiving and GoFundme are representatives of donation-based crowd- 
funding; while Early Shares, AngelList and CrowdCube are examples of equity-based crowd-funding companies.

\subsection{Lending Business Model}

Another major trend in Fintech is $\mathrm{P} 2 \mathrm{P}$ lending for consumers and businesses. P2P lending Fintechs provide consumers and businesses the possibility to lend and borrow money with low interest rates and a better lending process for both borrowers and lenders. These lending Fintechs are different from banks because they only help set up relationship between borrowers and lenders and charge them fees, while banks involved in lending themselves. This difference leads to the fact that P2P lending Fintechs do not need to satisfy requirements in terms of capital, which affect the lending amount, while banks do (Williams-Grut, 2016).

Fintech lending companies stand out with the use of different credit models, data analytics and online data sources to reduce costs, accelerate lending procedures and calculate risks. Nevertheless, this model's success rate depends on interest rates, which cannot be controlled by the companies in the field. The aim of P2P and crowd-funding Fintech companies are different. Crowd-funding is used to mobilize funding for projects, while P2P lending is for the re-financing of credit card and debt consolidation (Zhu et al., 2012). Typical examples of lending Fintechs are Prosper, Zopa, Lending Club, SoFi and RateSetter.

\subsection{Capital Market Business Model}

Fintech business models can be applied to various aspects of the capital market such as trading, investment, risk management, foreign exchange, and research, among which, trading is a potential capital market Fintech. Trading Fintechs help traders connect with investors for knowledge-sharing and discussion purposes; for buying and selling stocks and commodities; and for risk management in real time. Foreign currency transaction is another type of capital market Fintech business models. Traditionally, only financial institutions are able to perform this type of transaction. However, nowadays, individuals and SMEs can conduct foreign currency transaction around the world with much less cost and barriers thanks to Fintech. Fintech allows users to see pricing and to perform transactions in real time through mobile devices, with much lower cost and more friendly transaction methods to users. Magna, eToro, Robinhood, Xoom and Estimize are typical examples of capital market business model.

\subsection{Insurance Services Business Model}

Fintech companies following insurance services business model aim at developing the relationship between insurance companies and their customers. Data analytics was used for risk matching and calculation and for offering customers with appropriate services such as healthcare, car insurance, causality insurance or life insurance. In addition, Fintech insurance services companies also change the healthcare billing processes, which is highly appreciated by conventional insurance providers as they can collect data from new sources to facilities their current business model and analyze risks more effectively. Examples of Fintech companies following insurance services business model include CoverFox, Censio, Ladder, Sureify Labs and The Zebra.

\section{Application of Technologies in the Financial System of Vietnam}

Although Fintech is still a new term in Vietnam, there have been companies providing intermediary payment services since 2008 and nine of them were provided with operating license from the government (Nguyen, 2018). According to Nguyen (2018), there are 67 companies in the Fintech sector in Vietnam and $48 \%$ of these companies participated in payment activities and provided customers and retailers with online payment services or digital payment solutions (2C2P, VTPay, OnePay, VTCPay, BankPlus,VinaPay, VNPay, Senpay, NganLuong, ZingPay, BaoKim, 123Pay, etc.)

Several companies operate in fund-mobilization field (FundStart, Comicola, Betado, Firststep), money transaction (Matchmove, Cash2vn, Nodestr, RemittanceHub), Blockchain (Bitcoin Vietnam, VBTC Bitcoin, Copyrobo, Cardano Labo), personal financial management, POS management, data management, loan and information comparison (Timo, kiu, Loanvi, Tima, TrustCircle, Hottab, SoftPay, gobear, etc.). However, compared to neighboring countries, the number of Fintech companies in Vietnam is lower (Indonesia has 120 Fintech companies and Singapore has over 300).

According to Viet (2018), Fintech companies in Vietnam mainly concentrate in certain areas, while other areas are being "forgotten" such as community fund mobilization, credit, etc., despite the fact that there are market demands in these areas. In the future, Fintech companies can seize opportunities in these areas for their future development.

In addition, convenience stores and supermarkets are growing rapidly and gradually occupy an increasingly large market share, replacing traditional forms of shopping, which is also an opportunity for Fintech companies to develop more technology applications in payment, credit, and personal finance management as is the case in some countries such as the US, Korea and China.

\section{Challenges for Fintech Companies during Their Development Process in Vietnam}

The challenges and barriers which prevent Fintech's development in Vietnam in the future have been evaluated 
based on desk research and expert-survey research. A questionnaire was designed to gain insights from experts on the challenges/barriers of Fintech development in Vietnam. The results from desk research and expert-survey research showed that there are five challenges for Fintech development in Vietnam, which are (1) legal corridor; (2) infrastructure; (3) Fintech companies; (4) customers; and (5) human resources. From these five barriers, there are 14 detailed aspects. From these aspects, the authors provided experts with a questionnaire form on these challenges. The 5-point Likert scale was used, in which 1 indicated 'Strongly Disagree' and 5 indicated 'Strongly Agree'. The 5-point Likert scale is considered appropriate in the evaluation studies of customers and experts in the Vietnamese context ( Nguyen et al., 2016).

The survey results showed 40 experts' evaluation on the challenges of Fintech companies, whose scores were above average level (see Table 1). The challenges in terms of legal corridor were ranked from 3.92 to 4.26 , which showed the experts' agreement that the legal corridor did not effectively support Fintech companies. The time for updating, revising and supplementing the legal framework is still slow compared to the rapid development of technology (Nguyen, 2018).

Secondly, the technology infrastructure of banking system in Vietnam is not able to meet the high-tech requirements in terms of bank security (Dang, 2017). The experts agreed with the challenges in terms of infrastructure (the evaluation scores were from 3.56 to 3.97 , on average).

Thirdly, according to Nguyen (2018), Fintech companies in Vietnam tend to struggle in finding appropriate business models, management models and funding sources, which affect the development of the companies (Nguyen, 2018; Nguyen et al., 2020). The average evaluation score for challenges from the side of Fintech companies ranged from 3.26 to 4.08 , in which the aspect of limited financial resources received the lowest score. It showed that the financial aspect is not a significant barrier for Fintech companies.

Fourthly, Vietnamese customers are not using new technologies and services since they worry about the privacy of their personal data. In addition, Vietnamese people have the habit of using cash for a long time. These difficulties become barriers for Fintech companies (Viet, 2018). The average score for the challenges from the customer side ranged from 3.72 to 4.36 , which showed high level of agreement from experts that challenges come mostly from customers.

Fifthly, it is difficult to recruit high-quality personnel for Fintech companies. The average score for challenges in terms of human resources ranged from 3.15 to 4.26 , in which the aspect 'Idea conflicts between banks and Fintech companies' received the lowest score. The score showed that idea conflicts may not strongly affect the development of Fintech companies in Vietnam.

\section{Solutions for the Promotion of Fintech}

It can be seen that Fintech has an increasingly important role in the development of the banking system. In order for Fintech to thrive in accordance with its potential in Vietnam, the article suggests a number of policies:

Firstly, it is necessary to quickly complete the legal regulations on Fintech. Accordingly, it is necessary to establish rules and regulations for the Fintech ecosystem; and to focus on building a legal corridor to facilitate Fintech services and products.

Secondly, there should be policies on tax exemption and reduction, policies to support access to capital sources, and to create a favorable environment for investing in Fintech.

Thirdly, it is important to promote research and application of the benefits of block-chain technology and distributed ledger technology for quick application in the field of finance-banking and other fields

Table 1: Survey results on the challenges

\begin{tabular}{|c|c|c|c|}
\hline Challenges & $\mathbf{N}$ & Mean & SD \\
\hline \multicolumn{4}{|l|}{ Legal corridor } \\
\hline Insufficient legal corridor & 40 & 3.92 & 0.77 \\
\hline Many gaps in the legal corridor & 40 & 4.13 & 0.77 \\
\hline $\begin{array}{l}\text { Late amendments to the legal corridor } \\
\text { (which cannot catch up with changes } \\
\text { of the market) }\end{array}$ & 40 & 4.26 & 0.55 \\
\hline \multicolumn{4}{|l|}{ Infrastructure } \\
\hline Low system security & 40 & 3.97 & 0.71 \\
\hline Limited facilities at banks & 40 & 3.56 & 0.68 \\
\hline \multicolumn{4}{|l|}{ Fintech companies } \\
\hline Business models are not on track & 40 & 4.08 & 0.81 \\
\hline Financial resources are limited & 40 & 3.26 & 0.75 \\
\hline $\begin{array}{l}\text { Ways for connecting with banks are } \\
\text { limited }\end{array}$ & 40 & 4.05 & 0.79 \\
\hline \multicolumn{4}{|l|}{ Customers } \\
\hline $\begin{array}{l}\text { The ability to approach Fintech of } \\
\text { customers is not good }\end{array}$ & 40 & 3.72 & 0.69 \\
\hline $\begin{array}{l}\text { Worries about the security of personal } \\
\text { information }\end{array}$ & 40 & 4.26 & 0.72 \\
\hline The habit of using cash & 40 & 4.36 & 0.74 \\
\hline \multicolumn{4}{|l|}{ Human resources } \\
\hline Lack of high-quality personnel & 40 & 3.82 & 1.07 \\
\hline $\begin{array}{l}\text { The training of technical connection in } \\
\text { finance-banking field is limited }\end{array}$ & 40 & 4.26 & 0.68 \\
\hline $\begin{array}{l}\text { Idea conflicts between banks and } \\
\text { fintech companies }\end{array}$ & 40 & 3.15 & 1.01 \\
\hline
\end{tabular}


Fourthly, the abilities of human resources for Fintech application and management must be improved. There should be a mechanism to encourage human resource training and attract high-quality human resources for Fintech development.

Eventually, it is necessary to actively promote and popularize knowledge about Fintech, as well as information to limit risks in Fintech transactions, thereby helping to identify benefits from the application of technology that Fintech brings.

\section{References}

Accenture. (2016a). Global FinTech investment growth continues in 2016 driven by Europe and Asia, Accenture study finds. Retrieved January 10, 2020 from: https://newsroom.accenture. com/news/ global-FinTech-investment-growth-continues-in2016-driven-by-europe-and-asia-accenture-study-finds.htm

Accenture. (2016b). FinTech and the evolving landscape. Retrieved January 10, 2020, from: https://www.accenture.com/us-en/ insight- FinTech evolving landscape

BNY Mellon. (2015). Innovation in payments: The future is FinTech. Available at: https://www.bnymellon.com/_globalassets/pdf/our-thinking/innovation-in-payments- the-future-isFinTech.pdf

Dang, H. (2017). Fintech: What should Fintech Startup in Vietnam do? (Part 4). [online] Department of Science and Technology Ho Chi Minh City. Retrieved January 10, 2020, from: https:// doimoisangtao.vn/news/2017/10/30/fintech-bi-4.

Holland FinTech. (2015, March 20). The future of finance: The socialization of finance. Retrieved January 10, 2020, from: http://hollandFinTechcom/the-future-of-finance-thesocialization-of-finance/

International Trade Administration. (n.d.). 2016 top markets report: Financial technology. Available at http://trade. gov/topmarkets/ pdf/Financial_Technology_Executive_Summary.pdf

KPMG. (2015, December 14). H2 Ventures KPMG FinTech 100: Announcing the world's leading FinTech innovators for 2015. Retrieved January 10, 2020, from: https://home.kpmg.com/xx/ en/home/ insights/2015/12/ventures-kpmg-FinTech-fs.html

Lee, I. \& Shin, Y. (2018). Fintech: Ecosystem, business models, investment decisions, and challenges. Business Horizons, 61(1), pp.35-46.

Li, P. (2016). Current and future years of e-commerce. In I. Lee (Ed.), Encyclopedia of e-commerce development, implementation, and management (pp. 1031-1044). Hershey, PA: IGI Global.

Mollick, E. (2014). The dynamics of crowdfunding: An exploratory study. Journal of Business Venturing, 29(1), 1-16.
Nielsen, J. F. (2002). Internet technology and customer linking in Nordic banking. International Journal of Service Banking, 13(2), 475-496.

Nguyen, N. D., Nguyen, T. H., Dang, B. N., \& Nguyen, V. D. (2016). Factors affecting consumer's buying behaviour toward tourism products on internet: An empirical investigation of Hanoi Consumers. Journal of Economics and Development, $245,77-88$

Nguyen, T. O. (2020). Factors Affecting the Intention to Use Digital Banking in Vietnam. Journal of Asian Finance, Economics and Business, 7(3), 303-310. https://doi.org/10.13106/jafeb.2020. vol7.no3.303

Nguyen, V. D., Dang, Q. D., Pham, H. G., \& Do, K. D. (2020). Influence of Overconfidence and Cash Flow on Investment in Vietnam. Journal of Asian Finance, Economics and Business, 7(2), 99-106. https://doi.org/10.13106/jafeb.2020.vol7.no2.99

Nguyen, T. (2018). Financial technology development in Vietnam: Opportunities and challenges. [online] TapChiTaiChinh. Retrieved January 10, 2020, from: http:/tapchitaichinh.vn/ nghien-cuu-trao-doi/nghien-cuu-dieu-tra/phat-trien-congnghe-tai-chinh-tai-viet-nam-co-hoi-va-thach-thuc-142310. html.

PwC. (2016, March). Blurred lines: How FinTech is shaping financial services. Available at https://www.pwc.de/de/ newsletter/finanzdienstleistung/assets/insurance-insideausgabe-4-maerz-2016.pdf

Sanicola, L. (2016, May 26). Will FinTech help or hurt traditional advisors? CNBC. Retrieved January 10, 2020, from: http:// www.cnbc.com/2016/ 05/25/will-FinTech-help-or-hurttraditional-advisors.html

The Economist. (2015a). The FinTech revolution: A wave of startups is changing finance - for the better. The Economist, 415(8937), 13.

The Economist. (2015b). Ask the algorithm: Human wealth advisers are going out of fashion. The Economist, 415(8937), 11.

Viet, H. (2018). Vietnamese fintech companies compete in the market of 4.4 billion USD. [online] the leader. Retrieved January 10, 2020, from: https://theleader.vn/67-cong-ty-fintech-vietnam-canh-tranh-trong-thi-truong-44-ty-usd-1545295777760. htm.

Williams-Grut, O. (2016, May 23). Deloitte just trashed the hype around a $\$ 180$ billion FinTech market. Business Insider. Retrieved January 10, 2020, from: http://www.businessinsider. com/deloitte-report-marketplace-lending-not-significantplayers-peer-to-peer-2016-5

Zhu, R., Dholakia, U. M., Chen, X., \& Algesheimer, R. (2012). Does online community participation foster risky financial behavior? Journal of Marketing Research, 49(3), 394-407. 